\title{
«Servicio de Dios, beneficio del público y utilidad del Estado». La fundación de conventos franciscanos en la Nueva España, 1700-1821/
}

\author{
«Service of God, public benefit and utility of the State». \\ The foundation of Franciscan convents in New Spain, \\ 1700-1821
}

David Carbajal López

Universidad de Guadalajara, Centro Universitario de los Lagos

Los expedientes para la fundación de conventos franciscanos en Nueva España bajo los Borbones, muestran la multiplicidad de argumentos de su utilidad. Necesarios por motivos religiosos, pero también civiles; tanto para las localidades donde se instalaban como para la Corona. Más hubo esfuerzos por reducirlos a entidades exclusivamente religiosas, por parte sobre todo del fiscal Ramón de Posada.

Palabras clave: Conventos; Franciscanos; Colegios Apostólicos; Utilidad pública; Secularización.

The records from the establishment of Franciscan convents in New Spain under the Bourbon reign, shows a great variety of arguments about how the convents could be used. Aside from being necessary for religious purposes, we found that they were also important for civilian aims, for the localities where they were founded, and for the Crown. Nevertheless fiscal Ramón de Posada, among others, made efforts to force these convents to serve only as religious institutions.

Keywords: Convents; Franciscans; Apostolic Colleges; Public Utility; Secularizatio. 
El reinado de los Borbones es especialmente conocido en la historiografía mexicanista por su crítica a las órdenes religiosas. Diversos estudios recientes han abordado ya el tema, y en ellos existe cierto consenso sobre el fuerte impacto que tuvieron para los religiosos las reales cédulas de 1749 y 1753, que ordenaban la secularización de las doctrinas; es decir, la entrega al clero secular de las parroquias donde habían ejercido hasta entonces la cura de almas, a veces desde tiempos de la primera evangelización. A largo plazo, tales medidas tendrían por consecuencia el más absoluto declive de las órdenes, hasta llevarlas casi a su extinción, de forma que, afirma José Refugio de la Torre, la secularización fue «el pequeño grumo de nieve que se precipita colina abajo e incorpora elementos devastadores en su trayectoria». ${ }^{1}$

Implementada además de manera dramática, según ha destacado David Brading, la secularización fue seguida de una serie de visitas de reforma emprendidas para corregir los «vicios» de la vida interna de los conventos, de la reorganización de ciertos puntos de su vida institucional (por ejemplo la supresión de los comisarios franciscanos de México y Lima), y del cierre temporal de los noviciados. ${ }^{2}$ Todo ello contribuyó para que, hacia el cambio de siglo, el número de frailes disminuyera sensiblemente.

Estas reformas se inscriben en el amplio esfuerzo de los Borbones por reformar tanto la organización institucional eclesiástica como la cultura religiosa de su vasto Imperio. En cuanto a lo primero el objetivo era reforzar el control del clero a través sobre todo de una interpretación cada vez más amplia del Real Patronato, ${ }^{3}$ que no podía sino poner en cuestión la autonomía de los regulares, fundada en privilegios pontificios. Y en cuanto a la cultura religiosa, ya en ciertos medios próximos a la Corona se denunciaba a los frailes por ser causantes de la «superstición» de las clases populares, así como por el mal ejemplo que daban las querellas propias de los claustros, especialmente intensas con motivo de la elección de sus superiores. ${ }^{4}$

Desde luego, estos cambios se inscriben en el marco más general de las Reformas borbónicas. Interpretadas por varios autores como un adelantado proceso de contrucción del Estado, en fecha más reciente se ha visto

1 Torre, 2001, 110 y en general 113-136.

2 Brading, 1994, especialmente 77, 84-87 y 95-97. Véase asimismo Morales, 1993; Zahíno, 1996, 113-132, y las síntesis recientes de Rubial, 2010, 226-228 y García, 2010, 250-256.

3 La obra clásica sobre este tema es, sin duda, la de Farriss, 1995, quien habla directamente del paso del control «indirecto» al control «directo» del clero.

4 Al respecto, véase Sarrailh, 1974, 630-652. 
bien que no iban hasta poner en cuestión el Antiguo Régimen en su conjunto, y que dejaban espacios para la negociación, incluso en casos como los que citamos aquí. ${ }^{5}$ Ahora bien, en este artículo no entraremos más en los detalles de la historia institucional de las órdenes religiosas, que, como puede apreciarse, ha sido ya tratada, pues nos interesa más bien un tema de la cultura religiosa de la época: los motivos para justificar la fundación de un convento, específicamente franciscano, haya sido un colegio de misioneros apostólicos o una casa de frailes de las provincias observantes.

$\mathrm{Y}$ es que, en efecto, todo lo anterior no significa que en esta época se hubiera dejado de fundar conventos. Antes bien, la Corona misma fundó uno, de franciscanos descalzos, el de San Pascual del Real Sitio de Aranjuez, ${ }^{6}$ y por lo que hace a los reinos americanos apoyó sobre todo la creación de colegios franciscanos observantes de Propaganda Fide 7 . Lo veremos un poco más adelante. Ello era en buena medida por la utilidad que podían reportar a la Corona por sus actividades misioneras entre infieles, pero es importante destacar que, a lo largo del siglo XVIII, el rey nunca dejó de patrocinar el envío de franciscanos a tierras americanas, fueran de colegios apostólicos o de las provincias. En el caso de la Nueva España, donde la orden franciscana era además la más antigua y extendida del reino, podemos contar la licencia para cinco colegios apostólicos, los de Zacatecas (1704), México (1733), Pachuca (1762), Orizaba (1797) y Zapopan (1812), y para al menos otros ocho conventos de las provincias observantes de San Pedro y San Pablo de Michocán y Santiago de Xalisco, ${ }^{8}$ los de Irapuato (1765), Zamora (1790), Guanajuato (1790) y Silao (1791) para la primera, y los de Saltillo, Sayula, Santa Ana y Tepic para la segunda (1784). A ello debemos agregar otras solicitudes de fundaciones que no prosperaron por diversas razones. Sin estar en posibilidades de ser exhaustivos, hemos podido identificar otras once solicitudes: Guadalcázar (1757), Valladolid de Michoacán (1774), Tecalitlán (1787), Monterrey-Boca de los Leones (1792), Puruándiro (1797), Pátzcuaro (1806), Los Remedios (1811), Ángeles (1815), Culiacán (1804), Villahermosa (1813) y los cinco conventos solicitados por la provincia franciscana de Zacatecas (1793).

5 El panorama reciente más completo del tema de las reformas es sin duda Lempérière, 2004, especialmente $135-156$.

6 Atienza, 2008, 147-150; la misma obra en 27-69 nos ofrece amplios datos sobre la cronología de las fundaciones para los siglos XVI al XVIII.

7 Sobre estos colegios sigue siendo fundamental la obra de Sáiz, 1969; en el caso de los novohispanos, véanse también los trabajos reunidos en Román, 2008.

8 Sobre la solicitud de la provincia de Xalisco, véase Torre, 2001, 166-168. 
En este artículo, repetimos, nos proponemos analizar los expedientes generados por estas solicitudes conservados en las secciones Audiencia de México y Audiencia de Guadalajara del Archivo General de Indias, para examinar los argumentos que en esta época se utilizaban para justificar la fundación de nuevos conventos. Conviene sin duda recordarlo: las Leyes de Indias establecían claramente que debía pedirse la licencia real para ello, previa la del diocesano, la del virrey y audiencia del distrito, con una información de la necesidad, utilidad y «justas causas» de la fundación. ${ }^{9}$ Había que probar además que los religiosos contarían con lo necesario para mantenerse. Tratándose de los franciscanos, que no podían tener bienes ni fundaciones pías, había que probar que en la región habría «limosnas abundantes» para ellos, todo sin causar perjuicio a los conventos ya fundados. Por ello estos expedientes, normalmente muy extensos, contienen amplios informes de todas las partes involucradas, lo mismo las declaraciones de los vecinos de los lugares de los nuevos conventos, que los informes de autoridades civiles y eclesiásticas, además de los pareceres de los fiscales de la Corona, quienes además de ir guiando el intrincado camino de estos procedimientos, se constituían a veces en los principales obstáculos a vencer, como fue en particular el caso del fiscal Ramón de Posada (17931802) ${ }_{10}^{10}$ quien argumentó con amplitud contra la multiplicación de estas corporaciones.

Cierto, cada una de las partes podía insistir en un argumento específico. En una primera parte abordaremos los argumentos de contenido fundamentalmente religioso, y que giraban en torno al concepto del «pasto espiritual», formado por la predicación y los sacramentos, que debían estar al alcance de todos los fieles.

Un abundante vecindario desprovisto de ese pasto era sin duda el mejor argumento para una nueva fundación, mas no era el único. Veremos en una segunda parte que abundaban también los argumentos «civiles», digamos, pero profundamente locales. Aun si se trataba de colegios apostólicos, cuyos misioneros podrían recorrer grandes distancias, las fundaciones se justificaban en buena medida por su utilidad al «público», esto es, a los habitantes de los lugares donde se establecían. Los antecedentes de la orden en varios pueblos (dada la reciente secularización de parroquias, desde luego) se mezclan aquí con las inquietudes nuevas de las élites locales

9 Recopilación de Leyes de Indias, libro I, tít. 3. ${ }^{\circ}$, ley 1, «Que se funden monasterios de religiosos y religiosas precediendo licencia del rey».

10 Sobre Posada, Rodríguez, 1977. 
por contar, por ejemplo, con estudios de gramática y filosofía, con el honor de la patria y el mantenimiento del orden a través del combate a los vicios.

En fin, una tercera vertiente de argumentos está dirigida al actor que daba su licencia, el rey. Lo veremos con detalle. Los nuevos conventos podían contribuir a aumentar la extensión de sus dominios y a fortalecer la subordinación de sus vasallos. No era un asunto menor, menos aún en los primeros años del siglo XIX, cuando la crisis de la Monarquía ha desatado la revolución liberal y la de independencia. Hay ciertas solicitudes de conventos que son testimonio claro de que los frailes se tenían por útiles para la pacificación. De manera más general, podemos decir de antemano que todos estos expedientes nos confirman hasta qué punto muchos de los objetivos de la Monarquía no podían dejar de lado a las corporaciones tradicionales, por lo que aun si la Corona no formuló estrictamente un programa para reformar a todos los religiosos, es bien claro que seguían siendo útiles para ella.

Veremos también los argumentos en contra de los religiosos, algunos formulados desde el siglo anterior, por ejemplo a propósito de su número excesivo, pero en general tendientes a proteger su carácter religioso en el más estricto sentido del término. Y es que todos estos expedientes nos enseñan asimismo que, aun si hay una tímida secularización de los fines de estas corporaciones, se mantienen en los «reinos de la confusión», por parafrasear a Alain Cabantous, ${ }^{11}$ entre lo sagrado y lo profano.

\section{Del pasto espiritual al buen ejemplo}

Los expedientes de fundación de conventos franciscanos en la Nueva España del siglo XVIII nos recuerdan bien que la sociedad tenía entonces fundamentos religiosos. Continuando una tradición de varios siglos atrás, racionalizada al menos desde el siglo XIII, se entendía que los hombres se asociaban para buscar simultáneamente el «pasto corporal» y sobre todo el «pasto espiritual». ${ }^{12}$ Este último estaba constituido por los elementos necesarios para la salvación de los fieles, definidos como tales desde el Concilio de Trento: los siete sacramentos, incluyendo también la palabra divina a través de la predicación y el acompañamiento de los moribundos. Las comuni-

11 Cabantous, 2004.

12 Respecto a la cultura política de la Nueva España del siglo XVIII es fundamental la obra de Lempérière, 2004, 23-62. 
dades de religiosos, como cualquier otra corporación que se ocupara de estos asuntos, eran tenidas por útiles y necesarias para el vecindario en donde habían de instalarse, tanto más cuanto se tratara de una población abundante. En ello hay pocos cambios a lo largo del período que estudiamos aquí y existe incluso cierta unanimidad de pareceres entre todos los actores de las fundaciones. ${ }^{13} \mathrm{Si}$ en 1702 el futuro Colegio Apostólico de Guadalupe de Zacatecas era juzgado «convenientísimo» por los canónigos de Guadalajara, en primer lugar porque «serán muy útiles a los habitadores de aquella ciudad para su bien espiritual», en 1812 el fiscal del Consejo de Indias calificaba de «útil cuando no sea absolutamente necesario», el convento que se solicitaba para el santuario de Los Remedios, extramuros de la capital, en virtud de «la necesidad [que] tienen de pasto espiritual aquellos naturales». ${ }^{14}$

Hubo incluso expedientes en que la argumentación consistía casi en exclusiva en el tema del pasto espiritual: fue así en Guadalcázar, en 1757, cuya petición fue descartada por el Consejo considerando que, tratándose de un real de minas, su abundancia era pasajera, como lo confirmó un informe postrero del virrey Caxigal de la Vega ${ }^{15}$. Más afortunada en cambio fue la solicitud para un convento en Guanajuato, asimismo fundada sólo en el crecimiento de la población de dicho real de minas, «el más célebre y famoso que tiene el reino» a decir de su ayuntamiento. «La abundancia que hay de gentes» redundaba en la «urgentísima necesidad» de ministros de los sacramentos, o como lo decían los párrocos: «es preciso que a proporción de sus creces se añadan personas eclesiásticas para el pasto espiritual». ${ }^{16}$ La idea de la proporción aparece también en la solicitud de un colegio apostólico para la villa de Orizaba, con el cual habrían de completarse tres grandes establecimientos religiosos en la urbe, equidistantes y hasta en línea recta. ${ }^{17}$ En suma, una urbe bien poblada debía idealmente contar con una adecuada distribución del pasto espiritual, y ello era motivo de atención de sus autoridades, las municipales tanto como los representes regios, como debía ser en cualquier otro servicio del público.

13 Es el mismo argumento por el cual se insiste en esta época, por parte tanto de obispos como de magistrados civiles, en la división de parroquias. Véase para la Nueva España, Taylor, 1999, I, 117-119.

14 Archivo General de Indias (AGI), Guadalajara, 207, carta del Cabildo Catedral de Guadalajara al rey, Guadalajara, 11 de septiembre de 1702 y México, 2656, dictamen del ministro fiscal, Cádiz, 4 de marzo de 1812.

15 AGI, México, 1257, resumen del expediente.

$16 \mathrm{El}$ expediente de la fundación de Guanajuato en AGI, México, 1296.

17 Hemos tratado sobre este colegio en Carbajal, 2006. El expediente de su fundación en AGI, México, 1304. 
Mas no era un argumento exclusivo. No era menos motivo para la fundación de un convento el culto de las imágenes religiosas. Los frailes en este caso estaban ahí, cierto que para brindar la asistencia a los fieles, pero también para rendir homenajes a los simulacros de la Virgen y de los santos. No era un asunto menor, el propio Concilio de Trento había justamente declarado el valor de la veneración de imágenes y reliquias, que se había convertido en uno de los principales símbolos de la catolicidad..$^{18}$ Los seglares de la Nueva España parecen tener claro que por ello ameritaban bien una comunidad completa de sacerdotes a su servicio. Son bien representativos de ello las solicitudes de colegios apostólicos para Valladolid, Zapopan y Los Remedios. Bástenos detallar sólo el primer caso, iniciativa del canónigo Fernando Navas Arnanz, quien, originario de Segovia, buscaba en 1774 a los misioneros franciscanos para que a su cuidado pudieran «adelantar los cultos y proporcionadas exaltaciones a la emperatriz de cielos y tierra en su dicho titular de El Henar», imagen propia de su región natal. ${ }^{19}$

Mas el catolicismo de la época valoraba no sólo el fasto que caracterizaba al culto y adorno de las imágenes, sino también otras formas de oración, «interiores», digamos, como la meditación y la contemplación, que podían a veces llevar a verdaderos arrebatos místicos, pero que por lo común tomaban la forma de ejercicios espirituales..$^{20}$ Los frailes también eran requeridos para servir de guías para ello, o bien para ofrecer espacios para su práctica. El mismo canónigo Navas Arnanz proyectó así que el futuro colegio apostólico sería útil también porque en él se fundarían una Escuela de Cristo y una Congregación de la Buena Muerte ${ }^{21}$ una y otra corporaciones destinadas a la oración y a la meditación de la Pasión, a pláticas doctrinales y otros ejercicios dedicados a la formación de devotos. Los fundadores del convento de Silao tenían un proyecto semejante: el convento habría de servir también para que los vecinos pudieran «retirarse por algunos días de sus comercios e intereses mundanos» y preparar así una confesión general. ${ }^{22}$

18 Véase, por ejemplo, Christin, 1991 y la presentación de Carlos, 2008.

19 AGI, México, 1275, representación del canónigo Fernando Navas, Valladolid, 17 de octubre de 1774 .

20 Sobre estas prácticas devotas en el catolicismo en general, Châtellier, 1987, 48-63.

21 AGI, México, 1275, representación del canónigo Fernando Navas, Valladolid, 17 de octubre de 1774 .

22 AGI, México, 1298, «Testimonio del expediente promovido por D. ${ }^{a}$ Ana Josefa de Laris y D. Francisco Antonio de Múzquiz sobre fundación de un convento de religiosos franciscanos en la congregación de Silao», 1790, 2v-3. 
La guía de los frailes a los seglares devotos era especialmente importante para aquellos que ya estaban constituidos en corporaciones que seguían su carisma: las órdenes terceras franciscanas. Ya lo decía el síndico de Saltillo en su solicitud de un convento para esa villa: él sería un «imponderable beneficio» para los abundantes terceros de ella, quienes podrían así incluso ganar «innumerables indulgencias». ${ }^{23} \mathrm{Tal}$ es, en efecto, otro de los beneficios que hacían útil al convento, los perdones plenarios o parciales de la estancia en el Purgatorio que se obtenían gracias a algunas de sus prácticas piadosas, y que eran un elemento de la economía de la salvación católica particularmente bien apreciado por los habitantes del mundo hispánico. ${ }^{24}$

Ahora bien, tratándose de los franciscanos, aun si venían a fundar conventos en regiones evangelizadas desde antaño, no era menos importante entre los argumentos religiosos el que los frailes contribuirían a la interminable obra de la conversión de los infieles, en especial los del norte de la Nueva España. Fue un punto de especial relevancia, obviamente, en el caso de los colegios apostólicos de Zacatecas, Monterrey-Boca de los Leones y de Los Remedios. Lo decía el cabildo catedral de Guadalajara al rey en 1702: de los misioneros que se establecieran en Zacatecas se esperaba un «copioso fruto espiritual en los fieles», pero también que éste fuera «mayor en la conversión de los infieles» ${ }^{25}$ Unas décadas más tarde (1749), los misioneros debieron comprobar la eficacia de su labor, obteniendo varias declaraciones de distinguidos eclesiásticos elogiando su dedicación a la conversión por todos los medios: «ya con el ejemplo, ya con el cariño, ya con el predicar, ya con la dádiva y ya finalmente con servirles en un todo», según expresión de uno de los canónigos tapatíos ${ }^{26}$. En medio de testimonios a veces dramáticos de los sacrificios de los misioneros frente a los «bárbaros» del norte, los eclesiásticos y seglares declarantes hacían de su labor apostólica el más importante servicio «a mayor honra y gloria de Dios nuestro Señor». ${ }^{27}$

23 AGI, Guadalajara, 373, «Testimonio de la representación hecha por el cabildo, justicia, regimiento y vecindario de la villa de Santiago del Saltillo, sobre que se funde un convento de la orden de San Francisco en dicha villa», 1783.

24 Véase al respecto la explicación de Bazarte, 2001, 67-94 y el estudio de Lavrín, 1998.

25 AGI, Guadalajara, 207, carta del Cabildo Catedral de Guadalajara al rey, Guadalajara, 11 de septiembre de 1702

26 Biblioteca Nacional de España (BNE), manuscrito 12046, «Información recibida de oficio sobre lo conveniente, útil y necesario que es el colegio de los reverendos padres misioneros apostólicos de Propaganda Fide de Nuestra Señora de Guadalupe de la ciudad de Zacatecas y demás que en ella se expresa», 7v.

27 Para el tema de los misioneros franciscanos en el norte novohispano del siglo XVIII, bástenos remitir a Román, 2008. 
Hasta finales del período que tratamos, esta vocación estaba lejos de desaparecer. Es casi obvio decirlo, seguía siendo importante en las regiones del norte. El proyecto de colegio apostólico para fundarse ya en Monterrey o ya en el Real de San Pedro de Boca de Leones (actual Villaldama), fue una iniciativa del obispo fray Andrés Ambrosio de Llanos y Valdés, directamente «para reducir y convertir algunos de los muchos indios infieles que había en los confines de la diócesis». ${ }^{28}$ Mas era un argumento presente también en las fundaciones de las regiones centrales, que sin embargo nunca llegaron a tener conversiones vivas. El padre fundador del colegio de Orizaba, fray Juan Buenaventura Bestard, no dejó de citar entre sus causales la conversión de la «numerosa gentilidad» del norte de México. ${ }^{29}$ Doña Ana María de Iraeta evocó incluso el ejemplo de los jesuitas para pedir la fundación de un colegio de capuchinos que «propaguen la fe en Jesucristo». ${ }^{30}$

Por ese entonces no se trataba ya sólo de convertir gentiles, sino también de pelear contra los enemigos del catolicismo. Así lo decía en 1809, en su justificación de la necesidad del colegio apostólico solicitado para Puruándiro, el promotor fiscal de la mitra de Valladolid de Michoacán, José Felipe Vázquez: frente a los franceses que como Voltaire denunciaban la superstición de los frailes, o que como el emperador Napoleón los calificaban de inútiles, los misioneros eran necesarios como «defensores de la fe». Lo afirmaba claramente el letrado eclesiástico: «la fundación pretendida será para Michoacán el nuevo muro que le ponga a cubierto de los insultos con que los enemigos de la religión han combatido a tantos pueblos». ${ }^{31}$

En fin, la utilidad misionera de los franciscanos podía tener otro aspecto no menos importante: el buen ejemplo. No es un tema a subestimar, la publicidad de la religión por sí misma se estimaba como un bien invaluable en el Antiguo Régimen, ${ }^{32}$ y en este caso tenía además una dimensión didáctica, a veces la más propia de los religiosos, no siendo

28 AGI, México, 2679, resumen del expediente.

29 AGI, México, 1304, carta de fray Juan Buenaventura Bestar a Francisco Cerdá, Madrid, 4 de enero de 1797.

30 AGI, México, 2656, carta del virrey Francisco Xavier Venegas, México, 19 de marzo de 1811.

31 AGI, México, 2742, «Testimonio del expediente instruido sobre fundación de un colegio apostólico de Propaganda Fide de Pachuca en la ciudad de Pátzcuaro», dictamen del promotor fiscal Dr. José Felipe Vázquez, Valladolid, 12 de mayo de 1809. Más ampliamente sobre la retórica de la defensa de la religión contra los franceses, Terán, 1998.

32 Lempérière, 2004, 206-211. 
menos espectacular sus resultados que la predicación o las otras actividades misioneras.

Así era en particular en el expediente de Silao, en el que los fundadores y testimonios de la información de necesidad y utilidad destacaban la importancia de los frailes en «la instrucción de la juventud» porque «el ejemplo de los religiosos» serviría «de educación provechosa a los párvulos». ${ }^{33}$ Educación tanto más efectiva podríamos agregar con el Cabildo Catedral de Valladolid de Michoacán en su informe sobre la fundación de Zamora, pues podía incluso despertar nuevas vocaciones. Decían los canónigos: «con el trato, comunicación y buen ejemplo de estos ministros se aficionarán al estado religioso, y desprendiéndose de los placeres mundanos se retirarán al sosiego de los claustros, en donde asegurarán su eterna felicidad». ${ }^{34}$

De ahí que se estimara en particular que el nuevo convento contase con una comunidad completa que asegurara el cabal cumplimiento de su propia regla. «Sus efectos serán más maravillosos y edificativos mientras sea más estrecha la clausura», ${ }^{35}$ decía el alcalde mayor de Tepic en 1778. Los misioneros apostólicos, cuyos colegios se estimaban particularmente estrictos entre los observantes, serían incluso un buen ejemplo para los otros frailes. Lo decía el obispo Juan Cruz Ruiz de Cabañas en la justificación del colegio de Zapopan: el nuevo convento sería «un oportuno y vivo despertador de la santa pobreza y de la más exacta observancia y obediencia» para los padres de la provincia de Santiago de Xalisco. ${ }^{36}$

Atentos a la distribución del pasto espiritual, a rendir culto a las imágenes, a guiar las oraciones de los devotos, distribuirles indulgencias y servirles de ejemplo, no menos que a la conversión de los infieles y a la lucha contra los «enemigos de la religión», se diría que los franciscanos reunían en sí el modelo mismo de la catolicidad. Eran por ello valorados, como

33 AGI, México, 1298, «Testimonio del expediente promovido por D. a Ana Josefa de Laris...», $2 \mathrm{v}-3$. El tema de la educación por parte de los religiosos fuera de cátedras y escuelas, por ejemplo, por el púlpito y el confesionario, ha sido en general asociado a la educación de los indios, Gonzalbo, 1990a, 215-234.

34 AGI, México, 2640, «Testimonio de los autos sobre fundar un convento de San Francisco en la villa de Zamora a representación de fray Manuel Avella, provincial de la provincia de San Pedro y San Pablo de Michoacán», 1789, 58-58v.

35 AGI, Guadalajara, 372, «Testimonio de los autos formados en virtud de reales cédulas de Su Majestad sobre el informe que se ordena hacer acerca de las utilidades o inconveniencias que resulten o puedan resultar de acceder a la pretensión de la provincia de Santiago de Xalisco de esta ciudad para fundar conventos de San Francisco en los pueblos de Zacoalco, Sayula, Zapotlán el Grande y Tepic», 1783, 73v-76.

36 Portillo, 2000, 50. 
hemos visto por seglares devotos, por el clero en todas sus jerarquías entre párrocos, canónigos y obispos, no menos que por las autoridades civiles y la monarquía misma. Sin embargo, sobre todo en esta época, su utilidad no podía limitarse al «servicio de Dios».

\section{Instrucción, memoria, honor y orden del público}

Ya lo habíamos mencionado, todas las fundaciones que citamos aquí son, en principio, de utilidad del público o de la «república», es decir, de la comunidad, orgánicamente estructurada y gobernada, en la cual habrían de asentarse ${ }^{37}$ Hemos citado en particular la distribución de los sacramentos, pero hay también otros argumentos «civiles», digamos, de esa utilidad, que son los que examinaremos a continuación, mencionados por lo común por los ayuntamientos, magistrados regios o propuestos por los propios franciscanos. Entre ellos, ocupa un lugar primordial el de la instrucción, aquí sí en el sentido de apertura de escuelas y cátedras. ${ }^{38}$ Los franciscanos fueron muy solicitados para abrir escuelas: se les menciona entre los argumentos de siete fundaciones, las de Irapuato, Zamora, Guanajuato, Silao, Tepic, Saltillo y Culiacán, y en un antecedente de la de Orizaba.

Desde luego, la educación impartida en estas escuelas conventuales estaba dirigida ante todo a formar buenos cristianos, e incluso candidatos al clero secular procedentes de las élites locales. Mas como hemos visto se trata de una tarea que no está obligatoriamente relacionada con la vocación religiosa de los frailes, que podían educar sólo con su ejemplo. Los frailes ya eran útiles, pero lo serían «más si se obligan a la enseñanza de la juventud», como decía un vecino de Silao en $1789 .{ }^{39}$ Esta distinción es propia de los actores de la época. En la petición de licencia para el nuevo convento de Irapuato, los «vecinos republicanos» de esa congregación distinguían entre su utilidad para «el bien espiritual y salvación de las almas», y los «otros especiales beneficios a este lugar», que era donde contaban la apertura de escuelas. ${ }^{40}$

37 Sobre el concepto de «república», Lempérière, 2004, 65-71.

38 Para la historia de la educación novohispana en esta época, remitimos al clásico de Gonzalbo, 1990b.

39 AGI, México, 1298, «Testimonio del expediente promovido por D. a Ana Josefa de Laris...», $1790,23 \mathrm{v}$.

40 AGI, México, 1261, «Testimonio a la letra de los autos fechos sobre la fundación de la regular observancia de N.P. S. Francisco que pretende ejecutar la provincia de San Pedro y San Pablo de Michoacán en la congregación de Irapuato...», 1761, 23v-27. 
Éstas eran valoradas, en primer término, porque evitarían el enviar a los jóvenes a estudiar a otros puntos del reino, lo cual tenía riesgos no sólo económicos, sino morales, pues «viven muchos en ociosidad y libertad peligrosa» según decir del ayuntamiento de Zamora. ${ }^{41}$ De hecho, habrían de corregir un desorden de la juventud que algunos lamentaban incluso de la que vivía en sus pueblos, «que andan perdidos por las calles y plazas», como decía uno de los testimonios de Irapuato, y que sin estudios era «dejarlos casi inútiles a su patria», en palabras del obispo de Sonora. ${ }^{42}$ Más aún, las escuelas contribuirían a la prosperidad de los pueblos, pues con «el socorro de los estudios y buena crianza de sus hijos» nuevos vecinos habrían de instalarse en ellos. ${ }^{43}$

Los propios franciscanos parecen haber sido conscientes de que la apertura de escuelas o cátedras eran importantes para los vecindarios. La fundación del convento de Guanajuato tuvo sus mayores dificultades al enfrentarse con ella las provincias de Santiago de Xalisco, que tuvo la iniciativa, con la de San Pedro y San Pablo de Michoacán, que consideraba a esa ciudad entre sus territorios. Fue el guardián del convento de Celaya quien, en julio de 1782, se apresuró a presentarse por parte de la provincia michoacana ante el ayuntamiento de Guanajuato ofreciendo la fundación ideada por sus hermanos jaliscienses, pero mejorando sus términos, justamente con la apertura de unos «estudios generales» que incluyeran sendas cátedras de Gramática y Filosofía, aunque ni con ello logró ganar el apoyo inmediato de los regidores. ${ }^{44}$

Ahora bien, en varios de estos expedientes, los franciscanos parecieran ser útiles no sólo por instruir al público sino por recuperar parte de la memoria con la que se identificaban. En efecto, especialmente en el expediente de las fundaciones solicitadas por la provincia de Santiago de Xalisco, se trata de localidades que llegan a ser calificadas como «amantes de la religión franciscana», que antaño (antes de la secularización) habían sido doctrinas a su cargo, y que se hallaban bien dispuestas a levantar los antiguos conventos, aunque algunas tenían las iglesias parroquiales en rui-

41 AGI, México, 2640, «Testimonio de los autos sobre fundar un convento de San Francisco en la villa de Zamora...», 1789, 28v-33.

42 AGI, México, 1261, «Testimonio a la letra de los autos fechos sobre la fundación...», 1761, 37v-38; AGI, Guadalajara, 582, carta de fray Francisco Rousset a José Antonio Caballero, Culiacán, 28 de febrero de 1805 .

43 Ibidem, 27-27v.

44 AGI, México, 1296, «Testimonio del expediente promovido por la provincia de S. Pedro y S. Pablo de S. Francisco de Michoacán sobre fundar un convento en Guanajuato», 1787, 1-10v. 
nas por un terremoto de años atrás. Fue así en el caso de San Juan del Río (Durango) y, sobre todo, de Zapotlán, Sayula y Zacoalco, donde si las fundaciones no llegaron a prosperar por la pobreza de esos pueblos, los vecinos no dejaron de declararse con entusiasmo a favor del retorno de los franciscanos. Habían sido ellos «quienes los criaron y educaron en los sagrados dogmas» y de quienes «han mamado su doctrina desde el primitivo tiempo de la conquista», se decía en Zapotlán: ${ }^{45}$ mientras que en Sayula el capitán de las milicias locales agregaba un punto económico: «con lo que se gasta en tres ministros clérigos pueden mantenerse seis $\mathrm{u}$ ocho regulares». ${ }^{46} \mathrm{El}$ párroco de Zacoalco expresaba por ello sus temores en su informe a la mitra de Valladolid de Michoacán: «esta gente como criada por los religiosos es muy afecta a ellos y con esto habiendo religiosos no harán aprecio del cura ni de clérigos». ${ }^{47}$ Esa misma parroquia parece haber tenido algún problema previo de disputa entre el párroco y los feligreses sobre el pago de un ministro de pie fijo en el pueblo de Santa Anita, por lo que acaso los religiosos se habrían convertido ahí en parte de las disputas internas de la parroquia. ${ }^{48}$ En suma pues, las nuevas fundaciones podían ser también una forma de recuperar parte de lo perdido en la secularización de doctrinas, siendo ejemplo sobre todo de que la ausencia de los frailes no significó su olvido inmediato en la cultura religiosa de los pueblos de la época.

Si no había precedentes franciscanos en el pueblo, los expedientes nos muestran en todo caso que el establecimiento de sus conventos podía ser útil para el «honor local». Conviene tenerlo presente, la presencia de abundantes corporaciones religiosas en el espacio urbano era un timbre de prestigio no menor en la época, sinónimo de que se trataba efectivamente de una «república» bien provista y dotada en todos sentidos. ${ }^{49}$ Se advierte bien en el expediente de Zamora: el párroco Dionisio Sandoval y Rojas declaraba en 1779 que el convento era necesario por el «aumento de la villa», no tanto en población, sino sobre todo en «esplendor, cultura y policía»; más directamente, los canónigos de Valladolid de Michoacán en 1783 lo juzgaron útil «para el lustre y honor de aquella villa»; lo que confirmaban los

45 AGI, Guadalajara, 372, «Testimonio de los autos formados en virtud de reales cédulas de Su Majestad...», 1783, 47-55.

46 Ibidem, 97.

47 Ibidem, 186-189.

48 Ibidem, 128v. Para el tema de las disputas entre párrocos y feligreses en regiones otrora a cargo de franciscanos, Taylor, 1999, II.

49 Lempérière, 2004, 102-108. También las fundaciones de la Península hacían con frecuencia alusión al orgullo local, como muestra Atienza, 2008, 388-393. 
vecinos en 1786, por tratarse de una «población de considerable vasticidad [sic] en que se comprenden muchísimas familias de esplendor» ${ }^{50}$ Otro ejemplo claro es el de Puruándiro, donde los vecinos reunidos en junta el 28 de julio de 1795 declaraban la fundación útil para «lustre y aumento de este lugar»..$^{51}$

Por ello, las iniciativas de fundación eran en buena medida consideradas como expresiones del amor a la patria. Lo decían con claridad los fundadores de los conventos de Guanajuato y Pátzcuaro. Para el primero, fray José Antonio Verdín, la obra era producto de un «inflamado corazón» lleno «del amor patrio a esta ciudad», mientras que para don Manuel Antonio Barragán, promotor del segundo, era motivo para presentarse como «buen vecino» $\mathrm{y}$ «verdadero amigo de la patria». ${ }^{52}$ De ahí que fuera harto complicado convencer a un fundador de cambiar el destino de su iniciativa, como se comprobó en el caso de sor María Manuela de la Presentación, patrocinadora del colegio apostólico de Zapopan, quien insistiría en que Guadalajara tenía derechos a los beneficios que aquél generara, «por ser mi patria, por haber vivido y muerto en ella mis padres, y por haberse buscado en este suelo el caudal que me dejaron». ${ }^{53}$

$\mathrm{Y}$ cabe decir que esos beneficios podían ser directamente materiales, según hacían notar tanto los vecinos como los magistrados reales y los obispos. Varios de los expedientes tratan del «aumento de la población», que ya habíamos citado a propósito de la fundación de escuelas. Un nuevo convento podía con facilidad dar origen a un nuevo barrio, atraído por el propio «pasto espiritual» y servicios que ofrecía. En Purándiro, uno de los vecinos declaraba en 1796, cuando apenas se estaba en los primeros trámites para una fundación, que no llegaría a concretarse, que «ya solicitan muchos individuos solares para construir casas y tener su habitación inmediata al pretendido convento». ${ }^{54}$ En Silao varios de los declarantes anticipaban que «se extendrá mucho la población» con la llegada de los

50 AGI, México, 2640, «Testimonio de los autos sobre fundar un convento de San Francisco en la villa de Zamora...», 1789, 34v-36, 56-56v y 127-129.

51 AGI, México, 2678, testimonio anexo a la carta del virrey Marqués de Branciforte de 26 de junio de 1797, 11-15.

52 AGI, México, 1296, «Testimonio del expediente en que solicita el R.P. Fray José Antonio Berdín...», 1787, 2v-5; AGI, México, 2742, «Testimonio del expediente instruido sobre fundación de un colegio apostólico...», escrito de Manuel Antonio Barragán al ayuntamiento de Pátzcuaro, 4 de agosto de 1806.

53 Portillo, 2000, 64-65.

54 AGI, México, 2678, testimonio anexo a la carta del virrey Marqués de Branciforte de 26 de junio de 1797, 21-41 
frailes. De hecho, el subdelegado de dicha congregación presentaba como ejemplo al Colegio Apostólico de Nuestra Señora de Guadalupe, haciendo notar que, habiéndose éste instalado a una legua de Zacatecas, para entonces, en 1789, prácticamente se había unido la población a la ciudad, por lo que podía decir que gracias a los misioneros se poblaba el reino «hasta sus desiertos». ${ }^{55}$

La obra material, la fábrica del convento, podía ser por ella misma un factor importante a considerar. Decía el subdelegado de Boca de los Leones que, gracias a ella, se verían «socorridas muchas familias» en un momento de crisis de las minas de la región. ${ }^{56} \mathrm{Y}$ en general, el mismo subdelegado destacaba el aumento del consumo que traería la presencia de los frailes, aunque fueran pocos, lo que era un punto no menor en una región recién colonizada, en la que el convento servía también para fortalecer la presencia urbana española frente a los pueblos de indios de la región. Desde luego, también estaba la «piadosa industria» de los frailes, a decir del obispo Ruiz Cabañas, anticipando que los futuros misioneros de Zapopan emprenderían por sí la introducción del agua al pueblo, como efectivamente sucedería andando el tiempo..$^{57}$

En fin, no era menor tampoco la utilidad que los nuevos conventos podían reportar en el «combate de los vicios», esto es, de los pecados que traían consigo problemas de orden público por atentar a la moral, al honor e incluso a la tranquilidad, un tema que de nuevo reunía las preocupaciones de magistrados y eclesiásticos. Los clérigos tenían por útiles a los misioneros franciscanos porque contribuían a la «restitución de haciendas ajenas», a poner fin a «rencores, juegos, amancebamientos» y a llevar el nombre de virtud a lugares donde «la vergüenza no se conoce», como decían algunos párrocos de la Tierra Caliente michoacana. ${ }^{58}$ Tan es así que llegaron a encomendarles explícitamente la atención de la moral sexual, como hiciera el canónigo Arnanz con los futuros misioneros de Valladolid, quie-

55 AGI, México, 1298, «Testimonio del expediente promovido por D. a Ana Josefa de Laris...», 1790, 35-38v.

56 AGI, México, 2679, «Testimonio del expediente instruido sobre la fundación de un colegio apostólico de propaganda fide en este obispado del Nuevo Reino de León en cumplimiento de la real cédula que dentro se contiene», informe del subdelegado Francisco Xavier Pérez, 18 de abril de 1796.

57 Portillo, 2000, 49. Aunque se conoce bien la importancia de los proyectos episcopales novohispanos de esta época para sus capitales (por ejemplo Jaramillo, 1996, 45-66), es menos lo que se ha tratado sobre las órdenes religiosas, aunque destaca el trabajo de Loreto, 2000.

58 BNE, manuscrito 12046, «Información recibida de oficio sobre lo conveniente, útil y necesario que es el colegio...», 30-3v. AGI, México, 2742, «Testimonio del expediente instruido sobre fundación de un colegio apostólico...», informe del párroco de Zirahuen, 24 de septiembre de 1806. 
nes deberían atender a problemas «de urgente necesidad», como los embarazos de «una niña de reputación» o de «una casada ausente su marido». ${ }^{59}$

Cabe decir que los pueblos mineros parecían concernidos por este tipo de preocupaciones. De manera particular, los frailes eran necesarios para contener «los vicios y desarreglos con que comúnmente está asistida la gente vagante que ocurre a los minerales», según decía el ayuntamiento de Guarisamey. ${ }^{60}$ El subdelegado de Silao, que confirmaba esa misma imagen, veía en los frailes un remedio a la conducta de los mineros, quienes gracias a sus prédicas, «trabajando con fidelidad y con arreglo a la caridad y justicia no usurparán de los metales que benefician, no defraudarán el tiempo a su trabajo, ni omitirán el trabajar conforme a las leyes de minería». ${ }^{61}$

Así pues los religiosos no sólo distribuían al público el pasto espiritual, sino que podían lo mismo contribuir a su instrucción, ser parte de su memoria, reforzar su honor, aumentar su vecindario y ayudar a mantener el buen orden. Servidores de Dios, sin duda, lo que no evitaba que fueran útiles también en asuntos profanos tan diversos en los que se mezclaban, casi de forma cotidiana, sin que ello fuera reprochable para el honor de su hábito. Más no fueron sólo útiles para la religión y para el público, sino también para otro actor fundamental, para la Corona.

\section{Expansión de la monarquía y subordinación al rey}

Todos los expedientes que hemos venido analizando fueron preparados para ser presentados en principio ante el virrey o el presidente de la audiencia de Guadalajara, pero sobre todo ante el Consejo de Indias, por lo cual todos tienen en cuenta de manera particular la utilidad que los nuevos conventos representaban para la Corona. Aun si, como hemos dicho al principio, en esta época la Corona emprende diversos proyectos para reformar a las órdenes, en sus dominios tanto americanos como peninsulares, ${ }^{62}$ es de resaltar que no faltaron los argumentos a favor de las fundaciones, y varios de ellos fueron efectivamente bien considerados por los fiscales y conseje-

59 AGI, México, 1275, anexos a la representación del canónigo Fernando Navas, Valladolid, 17 de octubre de 1774.

60 AGI, Guadalajara, 363, testimonio anexo a la carta del intendente Francisco Xavier Urrutia a Antonio Ventura de Taranco de 13 de diciembre de 1795, 15-17.

61 AGI, México, 1298, «Testimonio del expediente promovido por D. a Ana Josefa de Laris...», 1790, 35-38v.

62 Además de las obras ya citadas al inicio, remitimos para el caso peninsular a Cortés, 1989. 
ros de la corte de Madrid. Desde luego, no pretendemos decir que éstos que analizamos hayan sido los únicos argumentos aceptados por los monarcas, ni es nuestro objetivo hacer aquí un estudio exhaustivo al respecto.

Si bajo la Casa de Borbón las prioridades de la monarquía parecen desplazarse hacia la economía política, ${ }^{63}$ poniendo en primer término la defensa militar y el aumento del real erario, se diría que los franciscanos se adecuaban bien a esas prioridades. Ya lo hemos señalado, no es una casualidad que la mayoría de los conventos que citamos aquí se hubieran relacionado con el tema de las misiones en el norte novohispano. Era ahí donde los frailes podían literalmente contribuir a la expansión de la monarquía, y no dejaron de recordarlo en sus solicitudes. Asi en la información levantada en 1750, el colegio apostólico de Zacatecas podía vanagloriarse de que «en útil de la real corona», había contenido el avance francés en Texas, pues, según palabras del guardián, contaban para ello con la voluntad de «seiscientos indios hábiles, industriosos, fuertes en la guerra y expertos en el manejo de la fusilería». ${ }^{64}$ Además, con su reclutamiento exclusivo de frailes locales, el colegio zacatecano era incluso tanto más útil cuanto que no obligaba a la Corona a pagar expediciones (misiones, se les llamaba) de frailes peninsulares como hacían los otros colegios «defraudando inútilmente su real erario».65

Una de las solicitudes relacionada de manera directa con los propios proyectos de la monarquía para las órdenes fue la de la provincia de Santiago de Xalisco, que en 1776 solicitó licencia para fundar cuatro conventos. La solicitud era consecuencia de las reformas borbónicas por dos vías, primero porque había sido la secularización de doctrinas la que había reducido a la provincia a un solo convento grande, la casa matriz de Guadalajara; pero además, había sido por órdenes de la Corona que los franciscanos de Xalisco se habían hecho cargo de una treintena de misiones en Sonora, la Pimería baja y Nayarit, así como habían sido propuestos para ocuparse de enviar frailes para la futura custodia de San Carlos de Sonora, un proyecto en que debían colaborar tanto colegios como provincias. ${ }^{66}$ Los nuevos conventos eran solicitados no sólo para darle nueva for-

63 Lempérière, 2004, 150-156. En el tema de la reforma de las corporaciones religiosas, Connaughton, 2010.

64 BNE, manuscrito 12046, «Información recibida de oficio sobre lo conveniente, útil y necesario que es el colegio...», 68-68v.

65 Ibidem, 52-53.

66 Sobre la secularización de las doctrinas de Xalisco y su experiencia misionera, Torre, 2001, y en concreto para el tema de la creación de la Custodia de Sonora, 46-47 y 330-331. 
malidad a la provincia, sino sobre todo para tener en ellos frailes suficientes para el recambio de misioneros, por lo que decía bien su procurador en la Corte, fray Manuel Riezu, en 1783, que eran para cumplir tanto «las obligaciones de su instituto religioso» como las «que se le han confiado por la piedad de sus soberanos». ${ }^{67}$ Tratándose de proyectos que habían sido en efecto autorizados e incluso formados por el propio Consejo, el fiscal Antonio Porlier no dejó de citar el punto entre los justificantes que consideró para apoyar ese expediente, que se concluyó de manera positiva en enero de 1784, considerando que las fundaciones serían útiles «en servicio de Dios y del rey». ${ }^{68}$

Algunos de los representantes de la Corona en el norte novohispano fueron también favorables a los nuevos conventos, que veían como una manera de consolidar la conquista de esas regiones. Un ejemplo claro fue el gobernador de Nuevo León, Simón de Herrera, quien sugirió que, si había de fundarse un colegio apostólico en ese obispado, fuera en el Real de Boca de Leones, para «contener y resistir los insultos de los indios bárbaros». ${ }^{69}$ Bruno Díaz Salcedo, intendente de San Luis Potosí, respaldo con entusiasmo la posible fundación en Valle de Matehuala por la provincia franciscana de Zacatecas, recordando que «estos pueblos y países se conquistaron más con sus apostólicas fatigas que con las armas y soldados». ${ }^{70}$

Ahora bien, no sólo las misiones norteñas eran muestra del servicio que los franciscanos rendían a la Corona. Podía haber un argumento económico. Lo hemos visto, se esperaba que los conventos contribuyeran al aumento de los vecindarios; algunos magistrados civiles, como el subdelegado de Silao, señalaban de inmediato que ello redundaría «en ventajas del Real Erario». ${ }^{71}$ Asimismo estaba el tema de la educación: la apertura de escuelas y de cátedras en los conventos no sólo beneficiaba al público, sino como decía un vecino de Culiacán, los convertía en establecimientos «en donde la juventud se instruya para ser después útiles al Estado». ${ }^{72}$ De ellos

67 AGI, Guadalajara, 372, representación de fray Manuel Riezu, Madrid, 28 de octubre de 1783.

68 Ibidem, informe del fiscal del Consejo, Madrid, 10 de enero de 1784.

69 AGI, México, 2679, «Testimonio del expediente instruido sobre la fundación de un colegio apostólico...», informe de Simón de Herrera al virrey, Monterrey, 22 de agosto de 1796.

70 AGI, Guadalajara, 363, carta del intendente de San Luis Potosí Bruno Díaz de Salcedo al rey, San Luis Potosí, 18 de noviembre de 1796.

71 AGI, México, 1298, «Testimonio del expediente promovido por D. ${ }^{a}$ Ana Josefa de Laris...», 1790, 35-38v.

72 AGI, Guadalajara, 582, «Copia del expediente de real cédula de 20 de febrero del mismo año sobre fundación de un convento de religiosos franciscanos en la villa de Culiacán», 3-7v. 
saldrían, en palabras del alcalde mayor de Tepic, hombres capaces «para sostener el honor y decoro del real pabellón». ${ }^{73}$ Esto es, su formación les permitiría seguir no sólo la carrera eclesiástica, sino también la civil, y convertirse ya en magistrados reales o en empleados al servicio de la Corona.

De manera más general, los conventos franciscanos podían siempre ser útiles para la promoción de la lealtad a la monarquía. Tal era uno de los motivos por los que se repite una y otra vez en estos expedientes la fórmula de que los conventos serían «útiles al Estado». Al respecto, contamos con declaraciones tanto de los notables locales, como de eclesiásticos y magistrados. La diputación de mineros de Guarisamey esperaba por ejemplo que del nuevo convento resultara «la subordinación no solamente al soberano, sino a sus jueces», en tanto que uno de los párrocos que declaró en la información de utilidad de la fundación de Pátzcuaro explicaba que: «El hombre instruido en las máximas del Evangelio entiende necesariamente las obligaciones de la subordinación al rey y a sus ministros». ${ }^{74}$ Lo confirmaba el intendente de Durango en 1795: los nuevos conventos eran útiles «a la observancia de la divina ley y veneración a las de Vuestra Majestad». ${ }^{75}$ Pero tal vez quien lo expresó con la mayor contundencia fue fray Juan Buenaventura Bestard en un largo escrito a favor de la fundación del Colegio Apostólico de San José de Gracia de Orizaba en 1797: «los mejores cristianos son los vasallos más útiles y más fieles, y que el radicar los pueblos con las verdades de nuestra fe y en la caridad cristiana es el medio más apropósito para asegurarlos en la verdadera paz y en la debida subordinación». ${ }^{76}$ Cabe decir que fray Juan Buenaventura no dudó en ilustrar de manera muy concreta los resultados de la predicación de los misioneros, pues remitió en anexo un recibo de la Real Casa de Moneda de México por la plata del rey restituida en el marco de una misión franciscana. ${ }^{7}$

Ahora bien, el tema de la lealtad monárquica se vuelve de actualidad en la segunda década del siglo XIX, en el marco de la guerra que estalla en 1810. Más aún, al menos dos de las fundaciones que tratamos, las de Los

73 AGI, Guadalajara, 372, «Testimonio de los autos formados en virtud de reales cédulas de Su Majestad...», 1783, 73v-76.

74 AGI, México, 2742, «Testimonio del expediente instruido sobre fundación de un colegio apostólico...», informe del párroco de Santa María, 1. de octubre de 1806.

75 AGI, Guadalajara, 363, carta del intendente Francisco Xavier Urrutia a Antonio Ventura de Taranco, Durango, 13 de diciembre de 1795. 1797.

76 AGI, México, 1304, representación de fray Juan Buenaventura Bestard, 16 de mayo de

77 Ibidem. 
Remedios y Villahermosa, fueron concebidas en buena medida como agentes de pacificación. ${ }^{78}$ De hecho, ya el expediente de la fundación en Pátzcuaro, iniciado en 1806 y llegado al fiscal de lo civil de México en los primeros meses de 1810, debió en buena medida su continuación y envío al Consejo de Indias por el nuevo contexto de la insurrección. El virrey Francisco Xavier Venegas lo remitió finalmente en 1811, afirmando con claridad que «en ninguna época son más necesarios los propagadores de las buenas máximas y sana moral que en la presente en que por desgracia la corrupción de costumbres ha hecho tan rápidos progresos en todas partes». ${ }^{79}$

Gracias al contexto de guerra, acaso ningún otro de los proyectos de fundación fue tan aplaudido por todos los involucrados como el que doña Ana María de Iraeta presentó para el Santuario de Nuestra Señora de los Remedios, extramuros de la capital novohispana, con vistas a la creación de un colegio apostólico de capuchinos. Además de las entusiastas expresiones de los párrocos de la región, la fundación fue declada «utilísima y casi necesaria en las actuales circunstancias de haberse trastornado el orden público por la insurrección» por el gobernador del arzobispado Isidoro Sáinz de Alfaro, en lo que coincidió cabalmente desde Cádiz el ministro fiscal del Consejo Supremo de España e Indias en marzo de 1812, pensando que eran necesarios eclesiásticos que «contribuyan a contener el torrente de los desastres que se experimentan en aquel reino». ${ }^{80}$

Algo distinto fue el caso de la fundación de un convento de recoletos proyectada por el capellán del Santuario de Nuestra Señora de los Ángeles, el bachiller José María Santiago, en 1815. Su autor no pensaba sino en una serie de acciones de gracias a la Inmaculada Concepción, a quien había acudido con otros devotos durante los años de guerra pidiendo por la libertad del rey Fernando VII y del Papa Pío VII; el convento no era sino una de esas retribuciones. ${ }^{81}$ Habría de fundarse, en sus propios términos: «para que haya almas que continuamente le estén dando las más rendidas gracias [a la Virgen] por los favores que le ha dispensado a Vuestra Majestad».82

78 En general, como lo ha señalado ya una importante historiografía sobre la guerra, los religiosos participaron activamente en ella, véase sobre todo Van Young, 2006, 373-547.

79 AGI, México, 2742, carta del virrey Francisco Xavier Venegas al ministro de Gracia y Justicia, México, 28 de julio de 1811.

80 AGI, México, 2656, carta del gobernador de la mitra de México Isidoro Sáinz de Alfaro, México, 13 de febrero de 1811 y dictamen del ministro fiscal, Cádiz, 4 de marzo de 1812.

81 Las otras eran gestionar en Roma la definición de la Inmaculada Concepción como dogma, y la fundación de un convento de religiosas recoletas. AGI, México, 2700, representación de José María de Santiago, Madrid, 11 de julio de 1815.

82 Idem. 
Aun si estas iniciativas fueron tramitadas con celeridad en el consejo, mandando abrir los expedientes necesarios para formalizar las fundaciones, no llegaron a ver el día más bien por falta de recursos para su mantenimiento, que no porque las autoridades dejaran de considerarlos útiles e incluso necesarios. En cuanto a las otras fundaciones que tampoco llegaron a concretarse, los obstáculos fueron de naturaleza muy diversa, desde la valoración de la incapacidad de la región donde habrían de asentarse para sostenerlos con sus limosnas, la falta de recursos asegurados para emprender la obra, la presencia de otros conventos en la comarca, la constancia de que eran poblaciones bien provistas de pasto espiritual, entre otros. Pero entre ellos jugaron un papel destacado los informes de los fiscales del Consejo de Indias, en particular los de Ramón de Posada y Soto, que examinaremos a continuación.

\section{Religiosos o perjudiciales}

Los fiscales de la Corona, tanto los de las audiencias de México y Guadalajara, como los del Consejo de Indias, tenían el deber de examinar todos estos expedientes y dar las indicaciones necesarias para el respeto de la legislación, protegiendo siempre las regalías de la Corona. Como hemos visto, el cumplimiento de su oficio no implicaba necesariamente una oposición acérrima a la fundación de nuevos conventos. En cuanto a los del consejo, si el fiscal Maldonado dio un parecer desfavorable a la de Guadalcázar en 1759, entre sus sucesores, Bernardo Caballero aprobó la fundación Irapuato en 1765, Antonio Porlier las de Sayula, Santa Anita, Saltillo y Tepic en 1784, y Juan Antonio de Uruñuela hizo lo propio con las de Zamora, Guanajuato y Silao en 1790 y $1791{ }^{83}$ En sus dictámenes, ninguno de ellos mostraba una preocupación particular a propósito de los nuevos conventos, más allá del cumplimiento de las Leyes de Indias. En cambio, quien sí parecía tener un proyecto más preciso para los frailes fue el fiscal Ramón de Posada y Soto (1793-1802), antiguo oidor de la audiencia

83 Los nombres de los fiscales del Consejo los hemos retomado de Gildas, 1972, 226-227. Los informes en cuestión: Guadalcázar: AGI, México, 1257, resumen del expediente; Irapuato: AGI, México, 1261, informe del fiscal, Madrid, 6 de marzo de 1765; los cuatro conventos autorizados a la provincia de Santiago de Xalisco: AGI, Guadalajara, 372, informe del fiscal, Madrid, 10 de enero de 1784; Zamora: AGI, México, 2640, informe del fiscal, Madrid, 6 de junio de 1790; Guanajuato: AGI, México, 1296, informe del fiscal, Madrid, 31 de octubre de 1790; Silao: AGI, México, 1298, informe del fiscal, Madrid, 12 de octubre de 1791. 
de Guatemala con una trayectoria importante como fiscal de la Audiencia de México. ${ }^{84}$

Posada ya se había hecho notar por sus dictámenes en México. De hecho, es él quien se convierte en el «obstáculo a vencer», por así decir, en el trámite del expediente de Zamora, que le tocó ver por estar sirviendo entonces (1784) también la fiscalía de lo civil. Llegado a la fiscalía de Nueva España del Consejo de Indias en 1793, le tocó examinar la solicitud de conventos para la provincia de San Francisco de Zacatecas (1794) y las de los colegios apostólicos de Orizaba (1797) y Puruándiro (1798). ${ }^{85}$

Pues bien, ¿qué era lo que reclamaba el fiscal de los religiosos? En buena medida, no otra cosa sino una dedicación exclusiva a actividades religiosas, es decir, no aceptaba otro argumento respecto a su necesidad y utilidad, que no fuera estrictamente el de la falta del pasto espiritual. Por ello, si algo impacta de los dictámenes de Posada, es el absoluto silencio en que pasa los argumentos respecto a la utilidad civil de los conventos que examina, incluso los que hacían referencia a su importancia para la Corona. El tema a discutir, en cambio, es el de la suficiencia de ministros. En el expediente de Orizaba, su primera observación contra el nuevo convento es que había referencias a otras corporaciones religiosas de la villa, que le llevaron a formar un cálculo de unos 43 sacerdotes presentes en ella, que «pueden administrar competentemente el pasto espiritual»; en el de Puruándiro, declaró que faltaban constancias de «que se haya experimentado falta de pasto espiritual [...] ni muerto persona del distrito que comprende sin sacramentos».

Asimismo, Posada se interesaba de manera particular por el cumplimiento estricto de los votos de los franciscanos, en primer término por la formación de una comunidad regular, que contara con suficiente número de religiosos para hacer vida claustral con ejercicios de coro, oración mental, conferencias espirituales, etcétera. Esto es, Posada esperaba religiosos verdaderamente tales, y para ello no citaba leyes o cédulas reales, sino bulas pontificias, en particular una del Papa Inocencio XI de 1652, dirigida contra los conventos sin capacidad para albergar suficientes religiosos. El prin-

84 Además de Rodríguez, 1977, véase AGI, México, 1884, relación de méritos de Ramón de Posada, Madrid, 14 de abril de 1789.

85 Los informes a los que aludimos son: expediente de la provincia de Zacatecas: AGI, Guadalajara, 363, informe del fiscal, Madrid, 7 de julio de 1794; Orizaba: AGI, México, 1304, informe del fiscal, Madrid, 26 de enero de 1797; Puruándiro: AGI, México, 2678, informe del fiscal, Madrid, 15 de octubre de 1798. Las siguientes citas proceden de estos informes hasta nueva indicación. 
cipal objeto de su desconfianza es la figura del fraile vagabundo, aquel que, lejos de su superiores, anda «entregado a la ociosidad», y que por ello ponía en peligro la distinción que les correspondía como personas eclesiásticas, pues «se familiarizan demasiado con los seglares». De ahí que en el expediente para la fundación de Orizaba, ante la iniciativa del padre fundador de enviar unos primeros frailes para instalar un hospicio y ocuparse de la obra, no dejase de insistir en que «nunca sería conveniente permitir a los religiosos tanto tiempo fuera de los claustros». ${ }^{86}$

Al revisar el expediente de Puruándiro, Posada llegó a pedir un informe del comisario general de Indias del número de religiosos presentes en cada convento de la Nueva España. Preparando una posible reforma general, que no llegó a concretarse, el fiscal propuso la supresión de los más pequeños, reuniéndolos con los más grandes. Así podrían salir sólo para «hacer misiones y otros ejercicios de piedad», pero «viviendo el resto del año en comunidad y renovando en la oración y el coro su fervor». ${ }^{87}$

En ese mismo sentido, se diría que para el fiscal era peligrosa en especial la mezcla de los frailes en cuestiones económicas. Lo vemos bien en su dictamen del expediente de Zamora en la Audiencia de México. La fundación se presentó por el ayuntamiento de esa villa con el respaldo de la orden tercera franciscana que en ella existía, la cual donaría sus bienes y rentas para el nuevo convento, operación que de inmediato el fiscal declaró «opuesta al instituto de San Francisco», es decir, a la observancia de la pobreza, como justificó citando para ello el derecho canónico. ${ }^{88}$

De ahí también que el tema más evidente de los dictámenes del fiscal sea el de la recolección de limosnas. Sobreviviendo de ellas exclusivamente los franciscanos, Posada se mostraba celoso partidario de cuidar que su número no fuera excesivo. En el caso de Zamora, se preocupaba por la cercanía de otros conventos que enviaban cuestores a la región; en el de Orizaba, más contundente, utilizó una comparación destinada a conocer buena fortuna en el siglo siguiente, la imagen de los limosneros como plaga, pues «acosaban a los criadores y cosecheros a manera de langosta».

$\mathrm{Al}$ respecto, el letrado recuperaba en sus dictámenes argumentos contra el exceso de conventos que se habían formulado ya en el siglo XVII, y que lejos de estimarlos de «utilidad pública», los hacían prácticamente un

\footnotetext{
86 AGI, México, 2735, resumen del expediente.

87 AGI, México, 2678, informe del fiscal, Madrid, 15 de octubre de 1798.

88 AGI, México, 2640, «Testimonio de los autos sobre fundar un convento de San Francisco en la villa de Zamora...», 1789, 96-98
} 
peligro para el público. En el expediente de Zamora, no dudaba en citar a Juan de Solórzano: «que estos conventos cuando son muchos gravan a la república y no pueden sustentarse con las limosnas de los fieles». En los casos de Orizaba y Puruándiro repetirá una cita del discurso 42 de la obra del canónigo Pedro Fernández de Navarrete Conservación de monarquías, que los declaraba «muy dañosos y muy perjudiciales para lo público». ${ }^{89}$

En fin, una última preocupación del fiscal era el de la seguridad de los fondos para las obras conventuales. Contrario al frecuente argumento de los expedientes, de dejar a la Divina Providencia la recaudación por vía de limosna de los recursos necesarios para llevarlas a término, ya bajo la guía de los propios frailes, Posada se mostró severo en que se informara con exactitud de los fondos disponibles. En los conventos pedidos por los franciscanos de Zacatecas, encargó sobre todo que los magistrados civiles dieran cuenta de si los pueblos «son capaces o no de soportar los gastos» y «hagan tasar el importe a que ascenderán». En Puruándiro sentenció: «no hay fondo necesario para los gastos del edificio material». La lógica era la misma: dedicados exclusivamente al cumplimiento de su regla, los frailes no tenían por qué ocuparse del financiamiento de sus propios conventos.

Congruente con su idea de que las fundaciones suponían varias dificultades, Posada propuso, tanto en Puruándiro como en Orizaba, reemplazarlas por otras vías: en el primer caso introdujo la posibilidad de dividir la parroquia, y en efecto se instruyó un expediente para ello; en el segundo solicitó se buscara un antiguo expediente para la fundación de una obra pía de misiones por parte de los jesuitas, de la que deberían hacerse cargo los padres agustinos de Veracruz. De hecho, se diría que el fiscal prefería que fueran clérigos quienes atendieran la falta de ministros del pasto espiritual, en el entendido de que tal era su deber y para ello contaban con los productos de sus beneficios. En su dictamen sobre Puruándiro, Posada hace un reproche muy claro contra aquellos eclesiásticos que habían apoyado la fundación: "por aliviarse de las cargas de sus respectivos ministerios echándoles sobre otros, sin advertir que son muy personales, que no excusan de responsabilidad a los que no trabajan por sí en la viña del Señor».

Sobre todo por lo que toca al tema de la clausura y de la limosna, el fiscal compartía en buena medida inquietudes de las reformas que ya se habían emprendido en la Península en el reinado de Carlos III, con resulta-

89 Para ésta y las siguientes referencias, véase idem y nota 77. Sobre el uso de estas mismas obras contra la abundancia de conventos en la Península, Atienza, 2008, 63-69. 
dos más bien pobres ${ }^{90}$ En su caso, también sus posturas encontraron límites. De los tres expedientes que aquí citamos, el primero, el de los diez conventos pedidos por la provincia de Zacatecas, terminó archivado en espera de que llegaran todos los informes solicitados, mientras que en el último, el de Puruándiro, el Consejo se conformó con lo pedido por el fiscal en cuanto a rechazar la fundación, pero no en cuanto a tratar de la supresión de otros conventos. En cambio, en el caso de Orizaba, tras dos vistas del expediente que resultaron en sendos informes negativos, el Consejo pasó por alto sus informes y autorizó la fundación del Colegio Apostólico de San José de Gracia el 4 de julio de 1797. Los consejeros únicamente justificaron su decisión en el escrito presentado por el padre fundador, fray Juan Buenaventura Bestard, y en lo informado por múltiples autoridades civiles y eclesiásticas en el amplio expediente. ${ }^{91}$ Acaso, pero no podemos más que suponerlo, no hacían sino mostrar prudencia ante una solicitud en que estaban involucradas élites poderosas, como los cosecheros de tabaco orizabeños.

En los años siguientes, luego de que Posada dejara la fiscalía del Consejo, se diría que su esfuerzo por introducir una separación más clara de los religiosos del ámbito de lo profano no tuvo mayor continuidad. Al contrario, ya lo hemos visto, las fundaciones franciscanas fueron mejor recibidas en el contexto de la guerra, directamente para hacer de ellas un instrumento de la pacificación. El ejemplo más claro es el del Santuario de Los Remedios, para el cual, en una curiosa vuelta de la historia, fue el padre Bestard, para entonces comisario general de Indias, el único que se opuso a una fundación que estaría en las cercanías de otros seis conventos y tres colegios apostólicos, y por ello, en este caso, lejos de «socorrer» a los pueblos «sería sí gravarlos con nuevas cargas». ${ }^{92}$

\section{Comentarios finales}

Aun si pocas llegaron a concretarse, las iniciativas de fundación de conventos franciscanos continuaron en el reino de la Nueva España bajo los Borbones, también en tiempos de las reformas, utilizando para justificarlas

90 Cortés, 1989, 137-202.

91 AGI, México, 1304, resumen del expediente, resolución de 4 de julio de 1797.

92 AGI, México, 2656, informe de fray Juan Buenaventura Bestard, 6 de octubre de 1819. 
argumentos tanto religiosos como profanos, lo mismo la utilidad de las repúblicas urbanas que la de la monarquía. Los frailes seguían representando bien casi todas las prácticas promovidas por la catolicidad desde el siglo XVI, desde el fasto del culto a las imágenes hasta las prácticas devotas más interioristas. Y al mismo tiempo, sus fundaciones servían ahora para la instrucción, para el aumento material y del honor de los vecindarios, no menos que para seguir extendiendo los dominios de la Monarquía Católica y arraigar la lealtad a su soberano entre los pueblos. Lo reconocen así los vecinos, los párrocos, los obispos, magistrados civiles e inclusive varios de los fiscales de la Corona.

Desde luego, los propios religiosos parecen bien conscientes de estos múltiples argumentos a su favor, y los utilizan para reorganizar sus institutos, «despojados» de las doctrinas que habían concentrado sus atenciones desde siglos atrás. Las nuevas fundaciones son en buena medida, lo repetimos, consecuencia de las reformas, y muestran bien que la propia monarquía no iba hasta proyectar la extinción completa de las órdenes. Y claro está, las provincias de San Pedro y San Pablo de Michoacán, Santiago de Xalisco y San Francisco de Zacatecas, no parecen tampoco conformes simplemente de iniciar una larga agonía -aunque sin duda hacen falta más estudios para conocer más a fondo sus proyectos-, mientras que los misioneros apostólicos están directamente expandiéndose por el reino. Aun si los resultados de estas iniciativas no fueron espectaculares, obtienen algunas licencias en puntos estratégicos, como reales mineros y regiones de reciente colonización del occidente y del norte, pero también en el centro, como fue el caso de Orizaba.

Hubo, lo hemos visto, esfuerzos por limitar esas fundaciones, pero lejos de tratarse de una oposición a las órdenes religiosas en sí mismas, o de un posible «secularismo» anticipado, se trata, o al menos así nos lo ilustra el caso concreto del fiscal Posada, de insistir en su protección como institutos religiosos. El fiscal asume que es deber de la monarquía el amparo de lo sagrado, incluido el honor del hábito franciscano, y actúa en consecuencia cuidando con mucho celo que se establezcan sólo conventos que puedan seguir sus reglas de forma estricta. Regalista, sin duda, ello no lo convierte de manera automática en enemigo de los franciscanos, como seguramente tampoco a muchos otros representantes de la monarquía, e incluso no dejará de hablar bien de algunos. Prueba de ello es también el tono de confianza de la carta que le dirigió fray Pablo Mugártegui «religioso grave y varón ejemplar» desde el colegio de San Fernando de México, 
según decir del propio fiscal, quien recordaba «el afecto que profesa[ba] a este colegio» durante sus años de fiscal en la audiencia de esa capital. ${ }^{93}$

Mas a pesar de los esfuerzos del fiscal, será el nuevo régimen liberal el que inicie otros proyectos de reforma más radicales, en medio de debates que ponían ya de manera más directa en duda y de manera pública la utilidad de los conventos franciscanos del antiguo virreinato de la Nueva España.

\section{Fuentes y bibliografía}

\section{Archivos}

AGI: Archivo General de Indias, Sevilla.

BNE: Biblioteca Nacional de España, Madrid.

\section{Bibliografía}

Atienza, Ángela: Tiempos de conventos. Una historia social de las fundaciones en la España moderna, Madrid, Marcial Pons / Universidad de La Rioja, 2008.

Bazarte, Alicia y García Ayluardo, Clara: Los costos de la salvación: las cofradías y la ciudad de México (siglos XVI al XIX), México, Centro de Investigación y Docencia Económicas, Instituto Politécnico Nacional, Archivo General de la Nación, 2001.

Brading, David: Una Iglesia asediada: el obispado de Michoacán, 1749-1810, México, Fondo de Cultura Económica, 1994.

Cabantous, Alain: Entre fêtes et clochers. Profane et sacré dans l'Europe moderne, $X V I I^{e}-X V I I{ }^{e}$ siècle, Paris, Fayard, 2004.

Carbajal López, David: De frailes y seglares. Los vínculos del Colegio Apostólico de San José de Gracia de Orizaba, 1793-1840, tesis de Maestría en Historia Latinoamericana, Universidad Internacional de Andalucía-Sede Iberoamericana Santa María de La Rábida, 2006.

Carlos, María Cruz de, Civil, Pierre, Pereda, Felipe y Vincent-Cassy, Cécile (comps.): La imagen religiosa en la Monarquía hispánica. Usos y espacios, Madrid, Casa de Velázquez, 2008.

93 AGI, México, 1304, carta de fray Pablo Mugártegui a Ramón de Posada, Colegio de San Fernando de México, 26 de julio de 1796. 
Châtellier, Louis: L'Europe des dévots, Paris, Flammarion, 1987.

Christin, Olivier: Une révolution symbolique: l'iconoclasme huguenot et la reconstruction catholique, Paris, Minuit, 1991.

Connaughton, Brian: «Transiciones de la cultura político/religiosa mexicana: el aguijón de la economía política», en Cervantes Bello, Francisco Javier, Tecuanhuey Sandoval, Alicia y Martínez López-Cano, María del Pilar (coords.): Poder civil y catolicismo en México, siglos XVI al XIX, Puebla, Benemérita Universidad Autónoma de Puebla, Universidad Nacional Autónoma de México, 2010, 447-466.

Cortés Peña, Antonio Luis: La política religiosa de Carlos III y las órdenes mendicantes, Granada, Universidad de Granada, 1989.

Farriss, Nancy M.: Clero y Corona en el México colonial. La crisis del privilegio eclesiástico, México, Fondo de Cultura Económica, 1995.

García Ayluardo, Clara: «Re-formar la Iglesia novohispana», en García Ayluardo, Clara (coord.): Las reformas borbónicas, 1750-1808, México, Centro de Investigación y Docencia Económica, Fondo de Cultura Económica, Consejo Nacional para la Cultura y las Artes, Instituto Nacional de Estudios Históricos de las Revoluciones de México, Fundación Cultural de la Ciudad de México, 2010, 225-287.

Gildas Bernard: Le secrétariat d'État et le Conseil Espagnol des Indes (17001808), Genève, Librairie Droz, 1972.

Gonzalbo Aizpuru, Pilar: Historia de la educación en la época colonial: el mundo indígena, México, El Colegio de México, 1990a.

Gonzalbo Aizpuru, Pilar: Historia de la educación en la época colonial: la educación de los criollos y la vida urbana, México, El Colegio de México, 1990b.

Jaramillo Magaña, Juvenal: Hacia una Iglesia beligerante. La gestión episcopal de fray Antonio de San Miguel en Michoacán (1784-1804). Los proyectos ilustrados y las defensas canónicas, Zamora, El Colegio de Michoacán, 1996.

Lavrín, Asunción: «Cofradías novohispanas: Economías material y espiritual», en Martínez López-Cano, María del Pilar, Wobeser, Gisela von y Muñoz Correa, Juan Guillermo (coords.): Cofradías, capellanías y obras pías en la América colonial, México, Universidad Nacional Autónoma de México, 1998, 49-64.

Lempérière, Annick: Entre Dieu et le Roi, La République. Mexico, XVI ${ }^{e}$-XIX ${ }^{e}$ siècles, Paris, Les Belles Lettres, 2004.

Loreto, Rosalva: Los conventos femeninos y el mundo urbano de la Puebla de los Ángeles del siglo XVIII, México, El Colegio de México, 2000.

Morales, Francisco: «Secularización de doctrinas ¿fin de un modelo evangelizador en la Nueva España?», en Actas del IV Congreso Internacional sobre los Franciscanos en el Nuevo Mundo (siglo XVIII), Madrid, Deimos, 1993, 465-495.

Portillo, Manuel: Apuntes histórico-geográficos del departamento de Zapopan (1889), Zapopan, El Colegio de Jalisco, Ayuntamiento de Zapopan, 2000. 
Rodríguez García, Vicente: «El fiscal Posada: índice para una biografía», Anuario de Estudios Americanos, XXXIV, Sevilla, 1977, 187-210.

Román Gutiérrez, José Francisco, Río Hernández, Leticia Ivonne del y Carrillo Cázares, Alberto (coords.): Los Colegios de Propaganda Fide. Su historia y su legado, Zacatecas, Gobierno del Estado de Zacatecas, Universidad Autónoma de Zacatecas, El Colegio de Michoacán, Ayuntamiento de Guadalupe, 2008.

Rubial García, Antonio: «Las órdenes mendicantes evangelizadoras en Nueva España y sus cambios estructurales durante los siglos virreinales», en Martínez-López Cano, María del Pilar (coord.): La Iglesia en Nueva España. Problemas y perspectivas de investigación, México, Universidad Nacional Autónoma de México, 2010, 215-236.

Sáiz Díez, Félix: Los Colegios de Propaganda Fide en Hispanoamérica, Madrid, s.e., 1969.

Sarrailh, Jean: La España ilustrada de la segunda mitad del siglo XVIII, México, Fondo de Cultura Económica, 1974.

Taylor, William: Ministros de lo sagrado. Sacerdotes y feligreses en el México de la segunda mitad del siglo XVIII, Zamora, El Colegio de Michoacán, Secretaría de Gobernación, 1999, 2 t.

Terán, Marta: «La Virgen de Guadalupe contra Napoleón Bonaparte. La defensa de la religión en el obispado de Michoacán entre 1793 y 1834», Estudios de Historia Novohispana, 19, México, 1998, 91-119.

Torre Curiel, José Refugio de la: Vicarios en entredicho. Crisis y desestructuración de la Provincia Franciscana de Santiago de Xalisco, 1749-1860, México, El Colegio de Michoacán / Universidad de Guadalajara, 2001.

Van Young, Eric: La otra rebelión. La lucha por la independencia de México, 1810-1821, México, Fondo de Cultura Económica, 2006.

Zahíno Peñafort, Luisa: Iglesia y sociedad en México, 1765-1800. Tradición, reforma y reacciones, México, Universidad Nacional Autónoma de México, 2001. 